\title{
COMMENT
}

DOI: $10.1057 /$ s41599-018-0130-8

\section{Towards decolonised knowledge about transport}

\author{
Tim Schwanen ${ }^{1}$
}

\begin{abstract}
For centuries the transport of people and goods across the globe has been shaped profoundly by Western and other colonialisms. Impacts on the development of infrastructures such as roads, railways and ports as well as transport flows within, to and from origins and destinations are increasingly documented. This essay proposes that expert knowledge about and way of knowing transport systems and practices in former and current colonies are at least as much shaped by Western colonialisms. It advocates a decolonisation of that knowledge and proposes a dual strategy of complicating, slowing down and disrupting existing expert knowledge about transport and of putting new concepts, theories and methodological practices in critical dialogue with each other and hegemonic transport research practices. It also emphasises that moving beyond transport expertise's colonial legacy is a project that should be led from outside historically emerged centres of knowledge production.
\end{abstract}

\footnotetext{
${ }^{1}$ Transport Studies Unit, University of Oxford, Oxford, UK. Correspondence and requests for materials should be addressed to

T.S. (email: tim.schwanen@ouce.ox.ac.uk)
} 


\section{Colonialism's enduring relevance}

$\mathrm{n}$ large parts of the world the current state of transport systems cannot be understood without due consideration for colonialism and coloniality-the

"long-standing patterns of power that emerged as a result of colonialism, but that define culture, labour, intersubjectivity relations, and knowledge production well beyond the strict limits of colonial administrations [and] is maintained alive in books, in the criteria for academic performance, in cultural patterns, in common sense, in the self-image of peoples, in aspirations of self, and so many other aspects of our modern experience" (Maldonado-Torres, 2007: p. 243).

The focus is usually on transport infrastructure when colonialism's significance to transport is discussed. Research has documented how roads, rail networks, ports and even airports were transformed or created across large parts of Africa, Asia and Latin America to facilitate colonial administration and economic extraction from the sixteenth century onwards (e.g., Corpuz, 1999; Pirie, 2009; Debrie, 2010; Oliete Josa and Magrinyà, 2017). Since such infrastructures tend to lock urban and economic development into path-dependent trajectories for long time periods, their structuring effects often persisted after countries gained independence.

Care should nonetheless be taken avoid what Blaut (1993:p. 1) has called Eurocentric diffusionism-the deep-rooted tendency to think of Europe as the source of diffusions "of culture, of innovation, of human causality" and "non-Europe [as] the recipient"-in thinking about colonialism and transport infrastructure. Indeed, other powers and forces may be equally if not more important in the evolution of transport infrastructures. European colonisers often appropriated and transformed precolonial networks and infrastructures of mobility and trade rather than create them a new (Ogborn, 2008; Charney, 2016). Charney (2016) claims that in the former British colonies of Burma and Ghana it was precolonial kingdoms rather than colonial states that had the most influence on government transport policies after independence. There are also important transport infrastructure legacies of US, Soviet and Chinese colonialisms across territories as diverse as the Philippines (Corpuz, 1999) and Tanzania and Zambia (Monson, 2009), and China's current attempts to recreate the silk route over land and sea through its Belt and Road Initiative (Callahan, 2016) highlight the importance of not restricting attention to Europe.

The effects of colonialism and coloniality on transport are not limited to infrastructure. At least as important have been the impacts on the knowledges about transport in former (and current) colonies generated and held by academics, planners and consultants, for which the shorthand expert knowledge will be used from here onwards. That knowledge remains deeply committed to hegemonic western ideas that are deemed to be more or less universally applicable. The "West" is of course an imprecise, non-coherent construct that denotes variegated formations, from the USA to Western Europe to Australia, and their different transport systems, institutions, worldviews, value systems and knowledge production processes. In this essay "western" is used to denote sets of discourses, institutions, practices, technologies and infrastructure (dispositives) seeking to address the (in)efficiency of transport and other problems in ways that have been contemplated and trialled extensively by planners and researchers in or from countries such as the USA, the UK or Australia.

Reliance on western expert knowledge about transport has been generative in Africa, Asia and Latin America-to be understood not as clearly bounded and separated territories but as historically constituted, strongly variegated formations that have co-evolved relationally and enmeshed with each other and the rest of the world. That knowledge has undergirded numerous interventions since the end of World War II by development banks, national governments, and NGOs seeking to develop roads, ports, rail and bus rapid transit (BRT) systems and formalise so-called informal transport services. It has also helped to shape initiatives in countries and regions that have not been colonised formally by, for instance, Spain or the USA, such as Central Asia after the demise of the Soviet Union (e.g., Pomfret, 2010).

To what extent interventions underpinned by western knowledge have been beneficial is not always clear: road congestion, sprawl, $\mathrm{CO}_{2}$ emissions, air pollution and social inequality have often intensified (UN Habitat, 2013; Rizzo, 2015; Priya Uteng and Lucas, 2018). This has many causes but, part of the explanation seems to be that the appeal of expert knowledge lies more in power and politics than in its ability to generate sufficiently context-sensitive understandings of the diverse and complex transport systems and practices in specific sites across the world. Borrowing from Ananya Roy's reflections on the state of urban theory, I propose that in expert knowledge about transport " $[\mathrm{h}]$ istorical difference (i.e., difference constituted through the long histories of colonialism and imperialism) is misread as empirical variation" (Roy, 2016:2013) and not seen as necessitating sustained reflection on its theoretical, methodological and philosophical basis.

Such reflection, and indeed a wider decolonisation of expert knowledge about transport, is long overdue. It will open up different ways of thinking not only about transport policy but also about everyday life, politics and urbanisation-just as has happened recently in urban studies (e.g., Robinson, 2006; Roy and Ong, 2011; Sheppard et al. 2013). Below I draw selectively on post- and decolonial thought (see Bhambra [2014] for a discussion of the differences and overlaps between them) to propose some ideas about how expert knowledge about transport might be decolonised, thereby contributing to a tradition of paradigmatic critiques of such knowledge with roots in Marxism, feminism and post-colonialism (e.g., Hurst, 1973; Hanson, 2000; Pirie, 2014). But I first need to describe prevailing expert knowledge in more detail and discuss some potential concerns about the radical reworking that I believe is required.

\section{Expert knowledge}

It is impossible to summarise the prevailing knowledge and ways of knowing transport in former and current colonies across the realms of academia, policy and consultancy. Neither is monolithic, and any attempt to render them homogenous fails to do justice to their differentiations and the debates between different communities of practice. Rather than as a Kuhnian paradigm (Kuhn 1996) they are better thought of as a discourse and set of practices within a Foucauldian dispositive-an arrangement of discourses, procedures, institutions, habits, moralities and materialities that responds to what is seen as a problem in a given context (cf. Foucault et al. 1980; Bussolini, 2010). Dispositives are multiple and heterogeneous, with threads sometimes reinforcing and at other times and places undermining or contradicting one another, and they both change continually and are characterised by substantial continuities (ibid.). Thus, in the transport case the nature of the problem(s) at stake differs across space and time, but efficiency of movement-ensuring faster and more reliable circulation of vehicles and people whilst minimising negative externalities such as physical harm to participants, noise or pollution -is often at the heart it. This mode of problematisation has strong roots in the history of planning for automobile transport 
across the West. It both spread across the planet since the early/ mid-twentieth century with colonialism, development aid, the rise of supranational institutions like development banks and the UN and globally operating consultancy firms and NGOs, and was refracted by and reworked in response to place-specific experiences beyond the West.

Other recurrent elements and continuities can be identified. There is, for instance, a strong reliance on concepts, theories and modes of thinking from engineering and economics, and to lesser extent quantitative or analytical geography and psychology-all as developed predominantly in countries like Australia, Japan, the Netherlands, the UK and the USA. The focus tends to be on flows of vehicles on networks, or on individuals and sometimes households constituted by co-resident individuals as (boundedly) rational sovereign actors. Transport system users are subjectified in other ways too, and conceptualisations from behavioural and social psychology are rather popular (Schwanen et al., 2011), but the possibility to quantify and model subjects' behaviour and traits circumscribe the subjectivities that are considered in analyses. More generally, expert knowledge of transport relies very heavily on quantification and econometric modelling; extraordinary effort is devoted to the development and refinement of often data-hungry tools as diverse as cost-benefit analysis and travel demand models. The use of those tools tends to be undergirded by traditional notions of scientific objectivity (Haraway, 1988) and empiricist and positivist worldviews, even if these tend to operate in the background rather than being discussed explicitly.

A corollary of this epistemological orientation is a privileging of universality over particularity, and Roy's (2016) claim that historical difference due to colonialism and coloniality is reduced to empirical variation is particularly germane to expert knowledge about transport beyond the West. A review of recent geographical research on transport in Africa, Asia and Latin America confirms that most studies at best adapt pre-existing conceptual and theoretical frameworks to accommodate empirical deviations from a (western) norm, and this holds for researchers in and from Africa, Asia and Latin America as well as their colleagues in western universities (Schwanen, 2018). The dispositive of which academic research on transport is part has become global in reach and orientation despite its disproportionate basis in western-and hence inevitably time and place-specific-philosophical ideas, methodological practices, theories and modes of problematisation.

\section{Wither global knowledge about transport?}

There is validity to the argument that global knowledge of transport is needed when success stories of transport policy in particular places-for instance, cycling in Copenhagen and Amsterdam (Sheldrick et al., 2017) or Bus Rapid Transit (BRT) in Curitiba and Bogota (Wood, 2015) - are easier than ever to mobilise and replicate elsewhere. It is also understandable that some transport experts resist the greater focus on historical and geographical particularity that examining coloniality demands if it risks the demise of generalisation in theorising and understanding transport systems and practices.

Nonetheless, as Roy (2016) suggests, there are important distinctions between the global, the universal and the general. The global and its formation-i.e., globalisation-can be understood in different ways and both terms are frequently critiqued. For Spivak (2004: p. 72), for instance, [g]lobalisation is the imposition of the same system of exchange everywhere", aided by quantification and increasingly digital technologies, and pursued to establish or enhance control and domination. This, however, is a critique of universalisation and the reduction of difference to deviation from an ultimately arbitrary norm that is taken to be valid always and everywhere (in spite of its time- and place-specific emergence). These processes should indeed be challenged when it comes to expert knowledge about transport, not only for reasons discussed above, but also because of how they shape the subjectivities open to transport researchers and professionals in and from former and current colonies. The latter risk becoming the transport expert equivalent to Fanon's (2008[1967]: p. 8) "Negro of the Antilles" in the early 1950s who was "proportionately whiter-that is, he [sic] will come closer to being a real human being-in direct ratio to his mastery of the French language."

More tentative, humble and respectful ways of creating global knowledge exist. One possibility is to follow the suggestion from cross-disciplinary scholarship inflected by post-structuralist and postcolonial theory (e.g., Stengers, 1997; Robinson, 2006; Roy, 2016) to start from studying a single case-a journey, vehicle, immobile person, station, city-wide bus network, etcetera-and to analyse how its constitution, qualities and capabilities are made possible by events and processes in other places and times. This ties that case to others elsewhere and begins to offer insight into the role played by the contemporaneous and past circulations and mobilities in which that case is implicated, including the construction of certain transport infrastructures and the development of racially segregated cities with separate neighbourhoods for colonisers, indigenous people and diaspora communities in the colonial era (as in, for instance, Kampala and Jakarta) as well as funding support and structural adjustment policies more recently. The resulting understandings can also travel when drawn upon in comparative analysis of other cases. In this process of mobilisation those understandings become not only more general but are also modified again and again-a critical point highlighted by geographers studying the circulation of government policies across the world (Peck, 2011; McCann and Ward, 2013). Generalisation in the production of academic knowledge about transport does not have to stem from or result in universalisation. And if new concepts, theories and methodological practices are developed from cases or borrowed from elsewhere through constructive and respectful engagement with extant alternatives, then bottom-up generalisations do not have to result in a proliferation of theories and understandings that are incommunicado with each other (Leitner and Sheppard, 2016). The prospect of mid-range concepts, theories and methodological practices that are relevant and useful to understanding transport systems and practices in vastly disparate parts of the world does not have to be sacrificed.

It is evident that global understandings of transport systems and practices remain possible and desirable. They need to be decoupled from universalisation and rooted in particular modes of generalisation. Decolonising expert knowledge about transport, therefore, entails a double movement. On the one hand, expert knowledge of transport needs to be complicated, slowed down and disrupted. On the other, new concepts, theories and methodological practices need to be put into circulation and critical dialogue with each other and hegemonic understandings and practices.

\section{Reconfiguring research practice}

But how to do all above? As a western, white male based in an academic institution with a complex colonial history I am not in the position to offer firm and definitive answers to this question. At most I can contribute to the identification of some provisional and tentative directions of travel that may help to decolonise expert knowledge about transport.

Complicate, slow down and disrupt expert knowledge. A first direction of travel is to open up "western" concepts, theories and 
methodological practices regarding transport. As Chakrabarty (2000:p. 16) suggests for social theory in general, there is no point in a postcolonial revenge in the sense of full-scale rejection and discarding of those concepts, theories and practices. Many have become indispensable -if also inadequate-to understand transport systems and practices beyond the "West" and continue to generate material effects through the planning and other interventions they enable and legitimise. Opening up is more appropriate and can be achieved by considering both their histories and effects.

The genealogies of concepts, theories and methodological practices need to be traced carefully, as many are not purely "western" but complex hybrids that are also inflected by colonial configurations. Consider, for instance, the seminal publications on port development by Taaffe et al. (1963) and Hoyle (2011 [1983]). Conceptual ideas developed by these authors were informed by experiences in and data from Sub-Saharan Africa and were subsequently advanced, reworked, rejected by other researchers in the western tradition. Transport studies as a research field and community has devoted little energy to documenting and critically reflecting on its own history, perhaps because it considered solving the problems that haunt real-world transport systems more important. Some of the existing historical accounts (e.g., Lay, 2005; Bonham, 2006; Boyce and Williams, 2015) need to be extended and rewritten to take account of how transport studies has been affected by, and contributed to, coloniality.

This historical sensibility needs to be complemented by analysis of the effects that the invocation of "western" concepts, theories and methodological practices in transport research has generated, and continues to do so, across former and current colonies. Some of the questions to be explored relate to what those concepts, theories and practices render visible and thinkable, and which power relations are enacted through their usage (beyond creating particular subjectivities for transport researchers in non-western contexts). Consider efficiency: It is key to the spatial sorting of flows at different speeds as epitomised in the design of separate sidewalks, cycle lanes, bus lanes, car lanes (Bonham, 2006); to the prioritisation in policy of certain groups of transport system users on the basis of values of time and reliability; and to the disciplining of public transport vehicle drivers and users to, respectively, stop and board or alight at designated sites. The normalisation of these efficiency-optimising ordering practices provides a cognitive framework that helps to legitimise the formalisation and even outright banning of "informal" transport services by minibuses, motorcycles, tricycles, rickshaws and pedicabs in many cities across Africa and Asia, including the Middle East and Central Asia. It also gives weight to arguments that all such services cause road congestion whereas many-most motorbike and tricycle taxi services, for instancecan rapidly cut through traffic jams (Rimmer, 1984; Bize, 2017; Doherty, 2017).

New circulations and dialogues. There is also a need for more affirmative action through the assembling of new concepts, theories and methodological practices, emerging from empirical research and engagement with post- and decolonial scholarship beyond both transport studies and most of the "mobilities turn"-a body of work across sociology, anthropology and geography that explores the mobilities of people, objects, ideas and practices as well their social implications (Sheller and Urry, 2006) yet also largely rooted in western thought (Esson et al., 2016; Priya Uteng and Lucas, 2018). An interesting line of enquiry informed by theory in development studies and requiring further elaboration centres on mobility as the material base to everyday lives (Esson et al., 2016). For many inhabitants of rapidly growing cities across Africa, Asia and Latin America transport or activities directly dependent on it, such as mobile street vending on busy intersections (Bize, 2017), are a key part of portfolio working if not their dominant livelihood. Reliable statistics on the significance of mobility as livelihood are extremely rare, but there are estimates that between 1 in 50 and 1 and 5 inhabitants of Uganda's capital Kampala is a boda boda (motor taxi) driver (Doherty, 2017). As in Lomé, Togo (Diaz Olvera et al., 2016), the motorbike taxi industry in Kampala absorbs much of the surplus labour of young men, often migrants from smaller cities and rural areas with dreams of upward social mobility, who are excluded from the formal employment sector.

Another promising development concerns the dialogue between postcolonial scholarship on infrastructure and anthropological research on transport. Challenging the tendency to understand African urbanism in terms of failure and lack, Simone (2004:p. 408) proposed to see people as infrastructure because informal activity as "complex combinations of objects, spaces, persons, and practices" provides invaluable connections and affordances that sustain everyday life. Informed by Simone's work and social theory's wider infrastructural turn (Amin, 2014), McFarlane and Silver (2017:p. 6) propose the similar concept of social infrastructure to denote "the connective tissue, often unpredictable, anchoring urban life in popular neighbourhoods across the urban world." Social infrastructure, they stress, is a process and needs work to be made and stabilised. These concepts shed a different, much more positive light than almost all expert knowledge on Kampala's boda bodas or Nairobi's matatus (minibuses) and the street vendors working at intersections. Nonetheless, as Doherty (2017) observes, there is a salient risk that exclusion and exploitation are overlooked into how urban informality functions as infrastructure. Traffic accidents, exposure to extreme levels of air pollution, abuse by vehicle or bicycle owners are a reality for numerous drivers, whereas motorbikes and minibuses may be experienced as exclusionary and oppressive by, respectively, disabled people and women. All these issues must be considered in any decolonial perspective on urban transport.

New concepts will also have to be elaborated, sometimes as an option (Mignolo, 2011) alongside more established ones. As transport's specification of the broader concept of informality, the term "informal transport" is widely used to denote a huge variety of transport services, including boda bodas and matatus. Yet, it is deeply problematic given the homogenisation it enacts and because it defines those transport services by what they seemingly lack. The term is discursively performative: if, as Sylvia Wynter (Wynter and McKittrick, 2015) contends, language coalesces with endogenous neurochemical regulatory processes in humans' brains, then the very term informal transport is complicit in the generation of place-specific cultures of disregard for and disinvestment in the transport services it describes. Alternatives exist-paratransit (e.g., Rimmer, 1984; Behrens et al., 2016) and indigenous transport (Mateo-Babiano, 2016) - but neither challenge the formal vs. its other hierarchy. New, non-dualistic ways of conceptualising transport services are required.

Experimentation with methods is at least as important as greater diversity in theorisation and conceptualisation. Various researchers have turned to Global Positioning System (GPS) technologies to examine the movements of matatus and boda bodas (Williams et al., 2015; O'Brien and Evans, 2018). If used unreflexively, the data created thus can become a new power/ knowledge complex through which formalisation and displacement of "informal" services proceeds. Yet, as O'Brien and Evans (2018) suggest, these technologies can also become an ice-breaker and basis for co-production with drivers, offering a unique 
window onto the use and experience of transport modes by drivers and passengers that surveys and interviews cannot afford.

The importance of epistemology and ontology. Still, the need for methodological experimentation does not stop with a turn towards modern technology. Feminist social science has influenced transport research (e.g., Hanson and Hanson, 1981; Kwan, 2000) but this holds more for quantitatively oriented versions than for post/decolonial feminism. The latter nonetheless holds enormous potential, for instance because of how it complicates well-intentioned attempts to give a voice to people whose perspectives are not captured in prevailing expert knowledge such as matatu drivers and boda boda clients (cf. Coddington, 2017) or because it promotes analysis strategies that "unsettle" in the sense of foregrounding and reworking the settler status of (western) scholars who want to "go native" (cf. Hallet, 2017).

Work along these lines sheds light on the epistemological complexities of research across boundaries resulting from colonialism and coloniality, and researchers interested in decolonising knowledge about transport should at least engage with thinking and practice that challenges the conventions of transport research. Especially when research concentrates on the everyday mobility of disadvantaged groups in formerly or currently colonised territories, inclusive co-production of knowledge about their transport practices, needs and experiences demands recognition of divergences of what knowledge and the world are taken to be. The question of how differences in the nature of knowledge and in "cosmologies, histories, geographies, languages, economies and socio-political contexts" (Cole, 2017) are to be acknowledged and reconciled cannot be answered in general. Grappling with coloniality nonetheless demands accepting the inseparability of the knower and the known and recognising the geopolitics of knowledge and of knowing (Mignolo, 2011): whose understanding of transport is valorised and which insights are appreciated is conditioned in myriad ways by coloniality and hard work is required to overcome locked-in customs. There are no blueprints, but useful starting points might be to allow any knowledge about transport to be contested and to respect "the unknowable, that which is radically withheld in an exercise of resistance to power, or that which is simply beyond our ken for any number of reasons" (Hallet, 2017:p. 10).

\section{Conclusions}

This essay is not favouring a wholesale replacement of expert knowledge generated by academics, planners and consultants with subaltern views from below. Working with the perspectives of, among others, matatu drivers and boda boda users in Africa and elderly in indigenous communities in Latin America is critically important but there remains a need for expert knowledge, for instance to help align different interests or balance short- and long-term considerations in planning processes. Decolonising such knowledge is rather about enabling new modes of problematisation and making acceptable other kinds of evidence in debates about planning in cities and states around the world, including former colonies of the West, regions such as Eastern Europe and Central Asia, and indeed countries like the France, the Netherlands or New Zealand.

Yet, if the reproduction of historical structures of privilege and domination within knowledge about transport is to be avoided, then its decolonisation should not be led from the institutes that have historically dominated the evolution of expert knowledge about transport. A double decentring is required. There is, firstly, a need for more input from disciplines and scholarly traditions that traditionally have played a limited role in transport research.
Secondly, given the situatedness of all knowledge (Haraway, 1988), leadership by transport researchers from/in territories under colonialism or coloniality is highly desirable. Transport academics in the traditional centres of expert knowledge production can play supportive roles through awareness raising (as this essay has sought to do), capacity building across places and disciplines, genuinely co-produced research, and changing their own research practices.

Received: 20 February 2018 Accepted: 22 May 2018

Published online: 03 July 2018

\section{References}

Amin A (2014) Lively infrastructure. Theory, Cult Soc 31:137-161

Behrens R, McCormick D, Mfinanga D (eds) (2016) Paratransit in African Cities: Operations, regulation and reform. Routledge, Abingdon, p. 328

Bhambra GK (2014) Postcolonial and decolonial dialogues. Post Stud 17:115-121

Bize A (2017) Jam-space and jam-time: Traffic in Nairobi. In: Beck K, Klaeger G, Stasik M (eds) The making of the African road, 58-85. Brill, Leiden, p. 290

Blaut JM (1993) The Colonizer's Model of the World: Geographical diffusionism and eurocentric history. The Guildford Press, New York, NY, p. 253

Bonham J (2006) Transport: disciplining the body that travels. Sociol Rev 54 (1_Suppl):57-74

Boyce D, Williams H (2015) Forecasting urban travel: Past, present and future. Edward Elgar, Cheltenham, p. 672

Bussolini J (2010) What is a dispositive? Foucault Stud 10:85-107

Callahan WA (2016) China's "Asia Dream": The belt road initiative and the new regional order. Asian J Comp Polit 1:226-243

Chakrabarty D (2000) Provincializing Europe: Postcolonial thought and historical difference. Princeton University Press, Princeton, NJ, p. 324

Charney MW (2016) Before and after the wheel: Pre-colonial and colonial states and transportation in mainland Southeast Asia and West Africa. HumaNetten 37:9-38

Coddington K (2017) Voices under scrutiny: feminist methods, anticolonial responses, and new methodological tools. Prof Geogr 69:314-320

Cole P (2017) An indigenous research narrative: ethics and protocols over time and space. Qual Inq 23:343-351

Corpuz AG (1999) The colonial horse: Railroads and regional development in the Philippines, 1875-1935. University of Philippines Press, Quezon City, p. 262

Debrie J (2010) From colonization to national territories in continental West Africa: the historical geography of a transport infrastructure network. J Transp Geogr 18:282-290

Diaz Olvera L, Guézéré A, Plat D, Pchet P (2016) Earning a living, but at what price? Being a motorcycle taxi driver in a Sub-Saharan African city. J Trans Geogr 55:165-174

Doherty J (2017) Life (and limb) in the fast-lane: disposable people as infrastructure in Kampala's boda boda industry. Critical African Studies 9:192-209

Esson J, Gough KV, Simon D, Amankwaa EF, Ninot O, Yankson PWK (2016) Livelihoods in motion: Linking transport, mobility and income-generating activities. J Trans Geogr 55:182-188

Fanon F (2008) Black skin, white masks. Pluto Press, London, p. 224. [1967]

Foucault M, Grosrichard M, Wajeman M et al. (1980) The confessions of the flesh. In: Gordon C (ed) Power/knowledge: Selected interviews and other writings, 1972-1977-Michel Foucault, 194-228. Pantheon Books, New York, NY, p. 280

Hallet VS (2017) Reading (for) decolonization: Engaing with life writing in Labrador's Them Days magazine. Cul Stud $\leftrightarrow$ Crit Method (in press). https://doi. org/10.1177/1532708617750176

Hanson S (2000) Transportation: Hooked on speed, eyeing sustainability. In: Sheppard E, Barnes TJ (eds) A Companion to Economic Geography, 468-483. Blackwell, Oxford, p. 556

Hanson S, Hanson P (1981) The impact of married women's employment on household travel patterns: A Swedish example. Transportation 10:165-183

Haraway D (1988) Situated knowledges: the science question in feminism and the privilege of partial perspective. Fem Stud 14:575-599

Hoyle BS (2011) Seaports and development: The experience of Kenya and Tanzania.. Routledge, Abingdon, p. 288. [1983]

Hurst MEE (1973) Transportation and the societal framework. Econ Geogr 49:163-180

Klopp JM (2012) Towards a political economy of transportation policy and practice in Nairobi. Urban Form 23:1-21

Kuhn TS (1996) The structure of scientific revolutions, 3rd edn. The University of Chicago Press, Chicago, IL, p. 226 
Kwan M-P (2000) Interactive geovisualization of activity-travel patterns using three-dimensional geographical information systems: a methodological exploration with a large data set. Transp Res C 8:185-203

Lay MG (2005) The history of transport planning. In: Button KJ, Hensher DA (eds) Handbook of transport strategy, policy and institutions, 157-174. Elsevier, Amsterdam, p. 860

Leitner H, Sheppard E (2016) Provincializing critical urban theory: Extending the ecosystem of possibilities. Int J Urban Reg Res 40:228-235

Maldonado-Torres N (2007) On coloniality of being: contributions to the development of a concept. Cult Stud 21(2-3):240-270

Mateo-Babiano I (2016) Indigeneity of transport in developing cities. Int Plan Stud 21:132-147

McCann E, Ward K (2013) A multi-disciplinary approach to policy transfer research: geographies, assemblages, mobilities and mutations. Policy Stud $34: 2-18$

McFarlane C, Silver J (2017) Navigating the city: dialectics of everyday urbanism. Transactions ofthe Institute of British Geographers 42(3):458-471. https:// doi.org/10.1111/tran.2017.42.issue-3

Mignolo W (2011) The darker side of western modernity: Global futures, decolonial options. Duke University Press, Durham, NC, p. 408

Monson J (2009) Africa's freedom railway: How a Chinese development project changed lives in Tanzania. Indiana University Press, Bloomington, IN, p. 216

O'Brien J, Evans J (2018) Informal mobilities and elusive subjects: researching urban transport in the global South, pp. 78-94. In: Priya Uteng T, Lucas K (eds) Urban Mobilities in the Global South. Routledge, London, p. 248

Ogborn M (2008) Indian Ink: Script and Print in the Making of the English East India Company. The University of Chicago Press, Chicago, IL, p. 288

Oliete Josa S, Magrinyà F (2017) Patchwork in an interconnected world: the challenges of transport networks in Sub-Saharan Africa. Transp Reviews (in press). https://doi.org/10.1080/01441647.2017.1414899

Peck J (2011) Geographies of policy: from transfer-diffusion to mobility-mutation. Prog Hum Geogr 35:773-797

Pirie G (2009) Air empire: British imperial civil aviation, 1919-39. Manchester University Press, Manchester, p. 272

Pirie G (2014) Transport pressures in urban Africa: practices, policies, perspectives. In Pleterse E, Parnell S (Eds) Africa's Urban Revolution, 133-147. Zed Press, London, p 320

Pomfret R (2010) Trade and transport in Central Asia. Glob J Emerg Mark Econ 2:237-256

Priya U T, Lucas K (2018) Urban Mobilities in the Global South. Routledge, London, p. 248

Rimmer PJ (1984) The role of paratransit in Southeast Asian cities. Singap J Trop Geogr 5:45-62

Rizzo M (2015) The political economy of an urban megaproject: The bus rapid transit project in Tanzania. Afr Aff (Lond) 114:249-270

Robinson J (2006) Ordinary Cities: Between modernity and development. Routledge, London, p. 226

Roy A (2016) Who's afraid of postcolonial theory? Int J Urban Reg Res 40:200-209

Roy A, Ong A (2011) Worlding cities: Asian experiments and the art of being global. Blackwell, Malden, MA, p. 374

Schwanen T (2018) Geographies of transport III: New spatialities of knowledge production? Prog Hum Geogr. 42:463-472 https://doi.org/10.1177/ 0309132517699925

Schwanen T, Banister D, Anable J (2011) Scientific research about climate change mitigation in transport: A critical review. Transp Res Part A: Policy Pract 45:993-1006

Simone A (2004) People as infrastructure: Intersecting fragments in Johannesburg. Public Cult 16:407-429
Spivak GC (2004) Death of a discipline. Columbia University Press, New York, NY, p. 136

Sheldrick A, Evans J, Schliwa G (2017) Policy learning and sustainable urban transitions: Mobilising Berlin's cycling renaissance. Urban Stud 54:2739-2762

Sheller M, Urry J (2006) The new mobilities paradigm. Env Pl A 38:207-226

Sheppard E, Leitner H, Maringanti A (2013) Provincialising global urbanism: A manifesto. Urban Geogr 34:893-890

Stengers I (1997) Power and Invention: Situating Science. University of Minnesota Press, Minneapolis, MN, p. 272

Taaffe EJ, Morrill RL, Gould PR (1963) Transport expansion in underdeveloped countries: A comparative analysis. Geogr Rev 53:503-529

UN Habitat (2013) Planning and design for sustainable urban mobility: Global report on human settlements 2013. Routledge, Abingdon, pp 344

Williams S, White A, Waiganjo P, Orwa D, Jacqueline Klopp J (2015) The digital matatu project: Using cell phones to create an open source data for Nairobi's semi-formal bus system. J Transp Geogr 49:39-51

Wood A (2015) The politics of policy circulation: Unpacking the relationship between South African and South American cities in the adoption of bus rapid transit. Antipode 47:1062-1079

Wynter S, McKittrick K (2015) Unparalleled catastrophe for our species? Or, to give humanness a different future: conversations. In: McKittrick K (ed) Sylvia Wynter: On Being Human as Praxis, 9-89. Duke University Press, Durham, NC, p. 304

\section{Acknowledgements}

This article was completed with support from the PEAK Urban programme, supported by UKRI's Global Challenge Research Fund, Grant Ref: ES/P011055/1.

\section{Additional information}

Competing interests: The author declares that they have no competing interests.

Reprints and permission information is available online at http://www.nature.com/ reprints

Publisher's note: Springer Nature remains neutral with regard to jurisdictional claims in published maps and institutional affiliations.

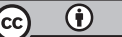

Open Access This article is licensed under a Creative Commons Attribution 4.0 International License, which permits use, sharing, adaptation, distribution and reproduction in any medium or format, as long as you give appropriate credit to the original author(s) and the source, provide a link to the Creative Commons license, and indicate if changes were made. The images or other third party material in this article are included in the article's Creative Commons license, unless indicated otherwise in a credit line to the material. If material is not included in the article's Creative Commons license and your intended use is not permitted by statutory regulation or exceeds the permitted use, you will need to obtain permission directly from the copyright holder. To view a copy of this license, visit http://creativecommons.org/ licenses/by/4.0/

(C) The Author(s) 2018 